\title{
Recommendations for Promoting Patient Engagement in Chronic Care: A Consensus Conference Statement
}

Guendalina Graffigna ${ }^{1,2}$, Serena Barello ${ }^{1,2}$, Giuseppe Riva ${ }^{1}, M^{4}$ assimo Corbo ${ }^{3}$, Gianfranco Damiani ${ }^{4}$, Primiano lannone ${ }^{5}$, Albino Claudio Bosio ${ }^{1,2}$, Walter Ricciardi ${ }^{4}$

1. EngageMinds Hub - Consumer, Food \& Health Research Center, Università Cattolica del Sacro Cuore (Italy);

2. Department of Psychology, Catholic University of Milan (Italy);

3. Casa di Cura Privata del Policlinico, Milan (Italy);

4. Department of Public Health, Università Cattolica del Sacro Cuore, Fondazione Policlinico 'Agostino Gemelli', Rome (Italy)

5. Higher Institute of Health, Rome (Italy).

\section{CORRESPONDING AUTHOR AT}

Dr. Serena Barello

EngageMinds Hub - Consumer, Food \& Health Research Center

Università Cattolica del Sacro Cuore

L.go Gemelli 1, 20123 Milano (Italy)

Mail: serena.barello@unicatt.it

Phone: +390272343863 


\section{ABSTRACT}

Patient engagement is receiving a growing attention in the healthcare context. However, although worldwide healthcare stakeholders agree that patient engagement is a priority for quality and effective care, no shared recommendations on how to promote patient engagement are currently available. Based on these premises, a Consensus Conference (CC) was promoted to address four main issues: What is the definition of Patient Engagement? How measuring Patient Engagement? What are the most recommended methodologies and the tools to promote Patient Engagement? What is the role of new technologies in promoting of Patient Engagement?

The consensus was obtained through an iterative process that began with a systematic synthesis of the available literature in each domain followed by plenary expert discussions.

This CC - including the systematic analysis of internationals scientific evidences (2749 sources across the major international scientific databases) together with experiences of a multi-disciplinary consortium of investigators and key stakeholders - attempted to provide the first evidence-based Expert Consensus Statement for the promotion of Patient Engagement in chronic care.

These recommendations should be envisaged as inspirational principles to promote a real eco-system of engagement and might orient health services research and interventions.

Key words: patient engagement; consumer health; recommendation; consensus conference; guidelines; health services research 


\section{Introduction}

The occurrence of new environmental risk factors, as well as ones regarding the population's lifestyle, in parallel to deep demographic changes (as for example the increase of the elderly population) brought the contemporary health systems to face increasingly complex scenarios characterized by the growth of care requests in face of a worrisome scarcity of economical and human resources(1). Chronicity is therefore the new scenario that professionals and institutions have to deal with in order to develop effective and sustainable care responses. Dealing with chronicity means coming to terms with a longterm management of the patient as well as with the resulting costs $(2,3)$. Consequently, the promotion of an effective integration between healthcare organizations and territorial services and the optimization of the patient's therapeutic journey, which today are even more complex and articulated, becomes a priority(4). In light of this scenario, the concept of Patient Engagement gained more and more attention in healthcare both in the clinical and research fields $(5,6,15-20,7-14)$. The last decades, in fact, have witnessed a profound turning of care models towards a growing and increasing valorisation of the role of the individual, who is seen as an active and "expert" subject within the clinical care process wailing to co-create his/her own health (21-25). Furthermore, the care system finds itself involved with people that express their desire to have a more active role in all the phases of their healthcare journey and feel their illness experience valued(26-33). People wish to be more involved in the decision-making process related to their healthcare, they wish to be aware and thoroughly know all the possible treatment options, and the relative pros and cons(34-40). Even if researchers and clinicians agree with the ethical and pragmatic priority of Patient Engagement promotion, to this day there is no consensus regarding the definition of this concept and the more appropriate strategies and instruments to reach this objective. Patients and healthcare professionals' perspectives on the factors that could support or obstruct Patient Engagement have not yet been sufficiently studied and, to this day, there are no recommendations on the interventions that are more effective in reaching the goal of Patient Engagement.

\section{Methods}

Based on these premises, the Università Cattolica del Sacro Cuore (Milan, Italy) in collaboration with the Welfare General Directorate of Lombardy Region (Northern Italy), under the methodological supervision of the National Institute of Health (ISS), promoted a Consensus Conference to define shared recommendations for Patient Engagement. The Consensus Conference represented the occasion to promote a multidisciplinary and cross-disease discussion among scholars, healthcare professionals, national patient advocacy groups and policy makers to seek answers to the following issues:

1. What is the definition of Patient Engagement?

2. How measuring Patient Engagement?

3. What are the most recommended methodologies and the tools to promote Patient Engagement? 
4. What is the role of new technologies in promoting of Patient Engagement?

The methodological procedure adopted by this Consensus Conference (later described) followed the standard procedure defined by the Consensus Development Program of the United States' $\mathrm{NIH}$ (https://consensus.nih.gov/). The Consensus Conference Process developed over the years 2016-2017 following the process showed in figure 1 and detailed in the next paragraphs. Particularly, the traditional approach of Consensus Conference was combined with an extensive analysis of evidence based international scientific literature on these topics (see table 1) and an extensive survey of best practices and experiences to promote Patient Engagement. 3) The process of consensus development was formalized among experts based on the conduction of working groups with experts under the final supervision of a panel of jury to collate, analyse, discuss and rate existing clinical evidences about Patient Engagement and to share final recommendations. The Consensus Conference involved 104 experts in patient engagement promotion from diverse disciplinary backgrounds (i.e. medicine, psychology, sociology, nursing, management, public health, policy making, health engineering) in order to promote a trans-disciplinary and cross disease debate and to reach a broader consensus. Furthermore the Consensus Conference included representative from 14 patients and voluntary associations to speak for their community and on behalf of their direct care needs and illness experience.

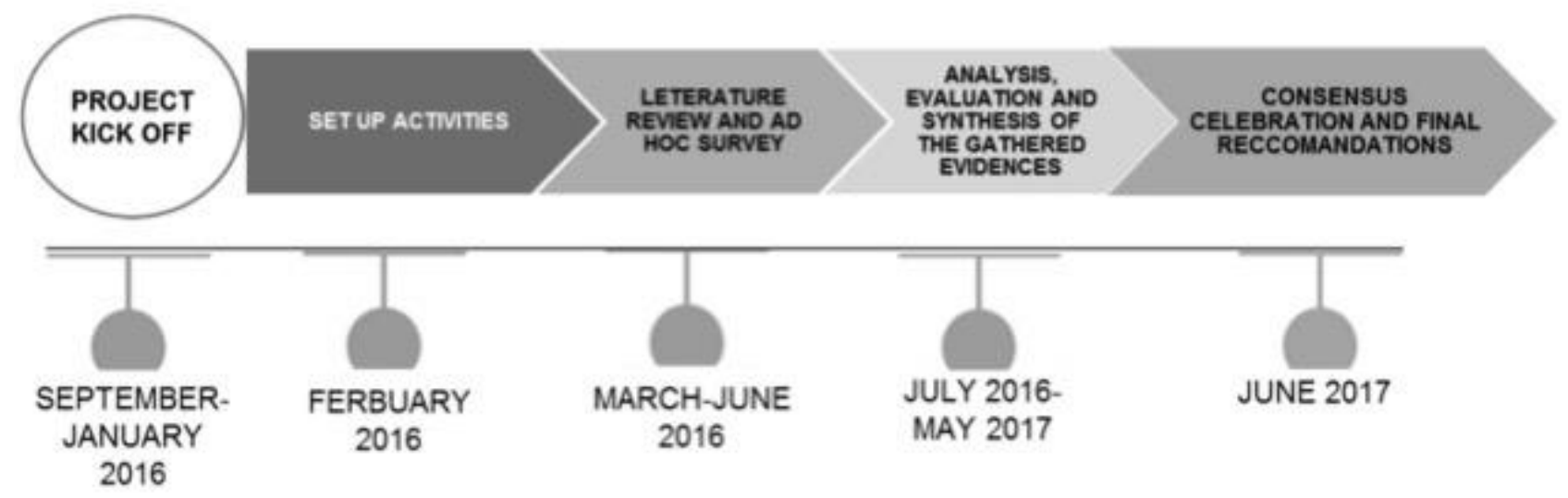

The entire methodological procedure was conducted under the supervision of the National Health Institute in order to guarantee its rigor and compliance with the NIH Consensus Developmental Standards. The methodological features of each phase of the Consensus Development are detailed in the next paragraphs.

\subsection{Review of scientific evidences}

A systematic revision of the international scientific literature published in English was conducted for the topic areas object of the CC using the following databases: Cochrane Library, Isi Web of Science, PubMed, Scopus, CINAHL, Psychlnfo. The literature review was executed with the creation of 2 search 
strings that corresponded with the areas of interest (definition and measurement; promotion of patient Engagement with/without technologies) following two different methods given the different nature of the queries and the relative bibliographical material (see table 1). The assessment of the methodological quality was conducted by a group of methodologist experts in scientific literature analysis. Here below is the methodology and the search strings used to analyse the scientific evidence in response to the queries raised by the CC.

Table 1 Methodological process of the analysis of the literature

\begin{tabular}{|c|c|}
\hline \multicolumn{2}{|c|}{ Analysis of the scientific evidence related to queries 1 and 2} \\
\hline Method: & $\begin{array}{l}\text { For queries } 1 \text { and } 2 \text { (related to the first search string), the experts were asked to do a narrative review of literature } \\
\text { given the nature of the object of interest and the analysed literature. The goal of this literature analysis was, in fact, } \\
\text { to further explore the nature and characteristics of concepts, theories and definitions of the phenomena of Patient } \\
\text { Engagement. It seemed appropriate to analyse the literature that, even when inspired by systematic criteria, } \\
\text { allowed a deeper and more critical analysis of the theoretical and conceptual components of the analysed studies, } \\
\text { as well and their empirical characteristics. Particularly, the analysis followed the principles of Conceptual Analysis, } \\
\text { widely spread in both social sciences and in welfare }(12,41,42) \text {. }\end{array}$ \\
\hline $\begin{array}{l}\text { Key words used in } \\
\text { the search strategy }\end{array}$ & $\begin{array}{l}\text { the databases listed above were subject to a systematic search according to the following keywords search string: } \\
\text { ["patient engag*" OR "consumer engag*" OR "client engag*" OR "citizen engag*"] AND ["definition" OR } \\
\text { "conceptualization" OR measure OR "questionnaire"]. No restriction was applied regarding the year, the language } \\
\text { or the document type. The search was integrated on the basis of an accurate analysis of the bibliographical } \\
\text { references reported in the studies found. }\end{array}$ \\
\hline $\begin{array}{l}\text { Inclusion criteria of } \\
\text { the studies }\end{array}$ & $\begin{array}{l}\text { In the analysis, only the manuscripts that reported a conceptual definition or a modelling theory of the concept of } \\
\text { patient engagement were included. The manuscripts were considered as "conceptual" if they discussed in depth } \\
\text { the epistemology roots of the analysis construct and that specified the theoretical and implementing components. } \\
\text { Careful attention was given to the modality of operationalizing and measurement of the theoretical constructs } \\
\text { proposed in the analyzed studies. The ones included were: Clinical Trial, Meta-Analysis, Practice Guideline, } \\
\text { Randomized Controlled Trial, Review, Clinical Trial, Controlled Clinical Trial, Guideline, Multicenter Study, Survey, } \\
\text { Case-Control Study OR Protocol, Retrospective Study, Cohort Analysis OR Cohort Study, Longitudinal Study, } \\
\text { Follow up OR Prospective Study, Observational Study, Qualitative studies, Quantitative studies, Expert Opinion } \\
\text { (Literature OR Analysis). }\end{array}$ \\
\hline Selection process: & $\begin{array}{l}\text { First, the database duplicates that generated from the systematic search were eliminated. At a later stage, all the } \\
\text { titles and abstracts found were read and analyzed with the aim of excluding sources irrelevant and incoherent with } \\
\text { the study inclusion criteria. Finally, the full texts of the sources left were read and thoroughly analyzed to understand } \\
\text { how they conceptualized, described and operationalized the concept of Patient Engagement. The process of } \\
\text { analysis of the sources was ongoing up until conceptual saturation was reached. }\end{array}$ \\
\hline $\begin{array}{l}\text { Process of analysis of } \\
\text { the evidence }\end{array}$ & 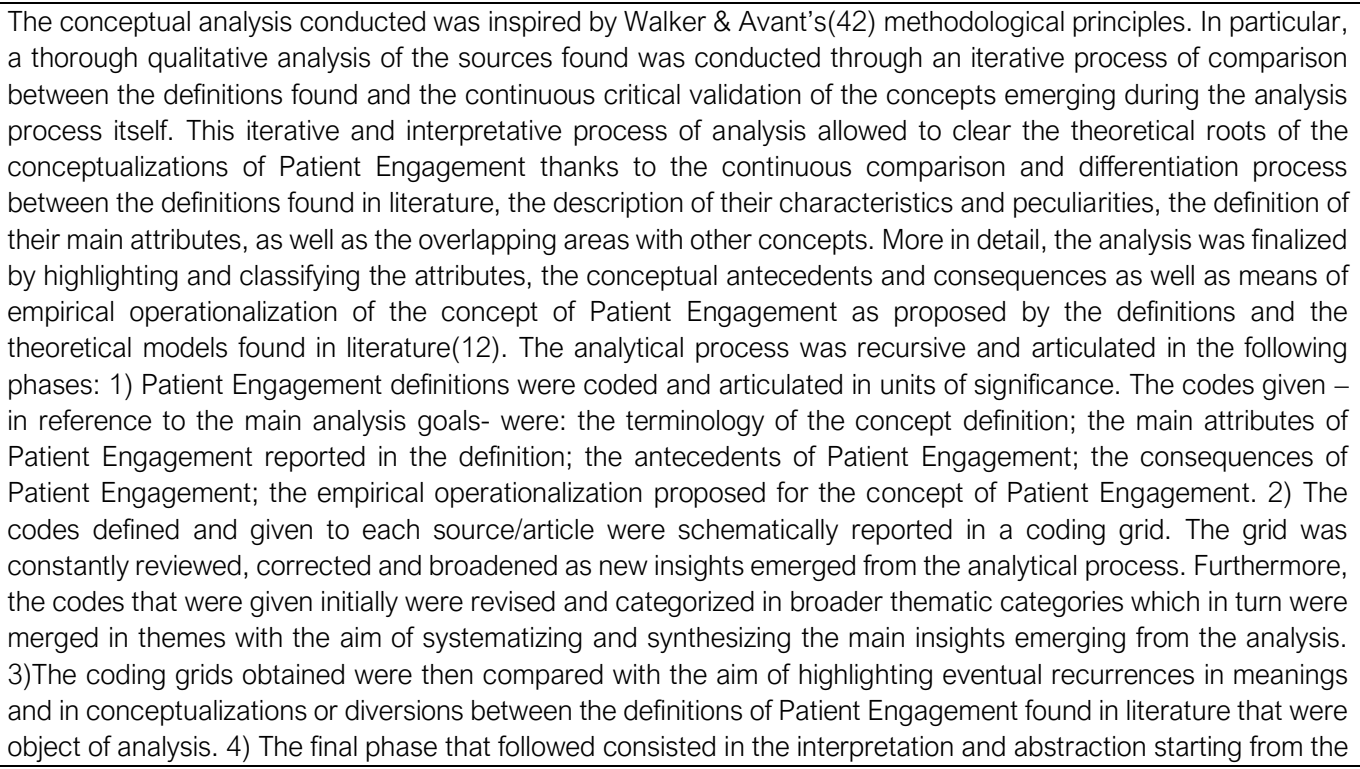 \\
\hline
\end{tabular}


comparative literature and the different analysis grids obtained. This final phase of the process allowed us to synthesize the main conceptual characteristics of the definitions found, and build a final taxonomy able to account for the conceptual attributes and the definition of Patient Engagement.

\begin{tabular}{|c|c|}
\hline \multicolumn{2}{|c|}{ Analysis of the scientific evidence related to queries 3 and $4:$} \\
\hline Method: & $\begin{array}{l}\text { for queries } 3 \text { and 4, the experts were asked to do a systematic literature review according to the methodological } \\
\text { principles of PRISMA - Preferred Reporting Items for Systematic Reviews and Meta-Analyses(43). Below the } \\
\text { methodological characteristics are detailed. }\end{array}$ \\
\hline $\begin{array}{l}\text { Key words used in } \\
\text { the search strategy: }\end{array}$ & $\begin{array}{l}\text { With the aim of answering queries } 3 \text { and } 4 \text {, the databases listed above were the object of a systematic research } \\
\text { conducted with the following search string: ("patient* engag*") AND ["plan"” OR "practice" OR "intervention*" OR } \\
\text { "program*" OR "protocol*” OR "trial*"]. No restriction was applied regarding the year, the language or the type of } \\
\text { document. The search was integrated on the basis of an accurate analysis of the bibliographical references } \\
\text { reported in the studies found. }\end{array}$ \\
\hline $\begin{array}{l}\text { Inclusion criteria of } \\
\text { the studies: }\end{array}$ & $\begin{array}{l}\text { the studies that were included in the analysis were coherent with the following inclusion criteria: (1) Years covered } \\
\text { by the research: all the literature produced until the year 2016; (2) Population: studies that explicitly discussed the } \\
\text { concept of Patient Engagement in the context of chronic illnesses; (3) Types of studies: with the aim of focusing } \\
\text { the analysis on the most significant scientific evidence, only studies with Randomized Controlled Trial were } \\
\text { included. }\end{array}$ \\
\hline Selection process: & $\begin{array}{l}\text { the identified studies underwent another selection through the analysis of the titles and abstracts, to which followed } \\
\text { an exclusion of those that were clearly unsuitable for the queries and inclusion criteria previously described. Of all } \\
\text { the selected abstracts the full texts were then obtained and divided per topic area (in reference to the CC queries) } \\
\text { and types of study. The systematic search of the sources was purposefully initially broad, in order to include all of } \\
\text { the potentially relevant studies for the study objectives. The articles found were then skimmed down and selected } \\
\text { using a funnel process. Specifically, during an initial selection phase all the sources found were analyzed with } \\
\text { regard to their title and abstract. This analysis allowed for the selection of only the relevant studies according to } \\
\text { the following criteria: (1) being a Randomized Controlled Trial; (2) referring to chronic patients; (3) presenting } \\
\text { measurement data of the impact of the intervention finalized to increase Patient Engagement; (4) being a peer- } \\
\text { reviewed article with full text availability. }\end{array}$ \\
\hline $\begin{array}{l}\text { Process of analysis of } \\
\text { the evidence }\end{array}$ & $\begin{array}{l}\text { the selected sources underwent systematic analysis with the aim of extracting the following information in a } \\
\text { structured analysis grid: (1) methodological characteristics of the study (country of the first author, study design, } \\
\text { number of branches of the study, type of control group, n. of participants in the experimental and control group) } \\
\text { (2) participants' characteristics (diagnosis, average age, \% per gender); (3) characteristics of the intervention } \\
\text { (number and duration of the sessions, type of treatment, strategies and instruments used both for groups and } \\
\text { single individuals, theoretical foundations of the intervention); (4) obtained results (measured outcomes, methods } \\
\text { of evaluation of the results, results achieved overall). The data extracted was then qualitatively analysed. } \\
\text { Evaluation of the quality of the studies: The quality of the RCT studies was evaluated following the Downs and Black } \\
\text { checklist, a solid instrument with good psychometric property (44) that has high levels of correlation with other } \\
\text { instruments of studies' quality assessment(45). This checklist allows to attribute a complex score of the } \\
\text { methodological quality of the considered studies (with a maximum score of } 27 \text { ) as well as a score on the quality of } \\
\text { the evidence reported (with a maximum score of } 11 \text { ), external validity (maximum score of } 3 \text { ), internal validity } \\
\text { (maximum score of } 7 \text { ), internal validity regarding the intervening variables (maximum score of } 6 \text { ). A final area of } \\
\text { the checklist allows us to give a score related to the adequacy of the sample size. The score relative to this item } \\
\text { will be simplified as follows: } 0=70 \% \text { (or impossible to determine), } 1=80 \%, 2=85 \%, 3=90 \%, 4=95 \%, 5=99 \% \text {. }\end{array}$ \\
\hline
\end{tabular}

\subsection{Analysis of best practices from the clinical field}

An ad hoc investigation was conducted regarding the good practices, instruments and methodologies used for the promotion of Patient Engagement. The investigation, coordinated by the Organization Committee, was done on a sample that was not statistically significant, but representative based on the research goals, and was formed by healthcare professionals that were selected in order to guarantee the multidisciplinary requirement. Data collection was executed through the diffusion of an online qualitative questionnaire in order to gather the experience gained by the experts on the initiatives and practices of the promotion of Patient Engagement, on the main targets of intervention and on the 
different instruments and methodologies that they use for the promotion of Patient Engagement. The investigation provided face-to-face workshops with experts. The investigation took place between March and April in 2016. All the collected questionnaires underwent normal quality checks before proceeding with data analysis. The data was analysed with the use of thematic analysis.

\subsection{Process of Consensus Development}

The experts involved in the Consensus were purposively selected on the basis of their previous renowned commitment and experience on patient engagement promotion both attested by previously published work, or due to generated outcomes during their work in the field (i.e. empirical research, patient engagement promotion initiatives; development of patient engagement tools or strategies). In order to guarantee the scientific standards of the process all members of the Consensus had to undersign a Conflict of Interest statement and the Consensus Conference Regulation. Particularly, in relation to this according to the methodology of the of the United States' NIH, an organizational structure for the whole Consensus Process was defined, as described in table 2.

Table 2 The role in the Consensus Conference

\begin{tabular}{|c|c|c|}
\hline ROLE & RESPONSIBILITIES & MEMBERS \\
\hline $\begin{array}{l}\text { Organizing } \\
\text { Committee }\end{array}$ & 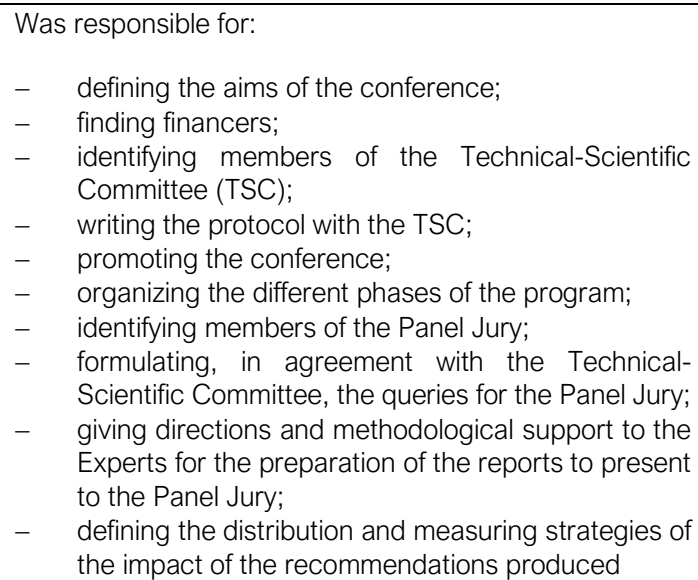 & $\begin{array}{l}\text { G. Graffigna, Università Cattolica del Sacro Cuore, Milano; } \\
\text { A.C. Bosio, Università Cattolica del Sacro Cuore, Milano; } \\
\text { S. Barello, Università Cattolica del Sacro Cuore, Milano; G. } \\
\text { Castelnuovo, Università Cattolica del Sacro Cuore, Milano; } \\
\text { M. Corbo, Casa di Cura Privata del Policlinico, Milano; G. } \\
\text { Riva, Università Cattolica del Sacro Cuore, Milano }\end{array}$ \\
\hline $\begin{array}{l}\text { Technical- } \\
\text { Scientific } \\
\text { Committee }\end{array}$ & $\begin{array}{l}\text { Was composed of members with recognized experience } \\
\text { and representativeness identified and invited by the } \\
\text { Organizing Committee and was responsible for: } \\
\text { - } \quad \text { collaborating with the Organizing Committee for the } \\
\text { writing of the Consensus Conference protocol; } \\
\text { - formulating the queries for the Panel Jury, in accord } \\
\text { with the Organizing Committee; } \\
\text { - internally designating its Experts and the eventual } \\
\text { work groups needed to prepare and present to the } \\
\text { Jury the reports of the single queries during the } \\
\text { conference; } \\
\text { providing the Experts and the work groups with the } \\
\text { necessary methodological directions to write the } \\
\text { assigned reports and make sure that a common } \\
\text { method is used to analyse data and present it to the } \\
\text { Jury. }\end{array}$ & $\begin{array}{l}\text { E. Anessi Pessina, CERISMAS (Centro di ricerche e studi in } \\
\text { management sanitario), Università Cattolica del Sacro } \\
\text { Cuore, Milano; R. Bellantone, Università Cattolica del Sacro } \\
\text { Cuore, Roma; R. Borgatti, IRCSS Istituto Eugenio Medea, } \\
\text { Bosisio Parini, Lecco; A. Celano, APMAR (Associazione } \\
\text { Persone con Malattie Reumatiche); A. Cicchetti, ALTEMS } \\
\text { (Alta Scuola di Economia e Management dei Sistem } \\
\text { Sanitari), Università Cattolica del Sacro Cuore, Roma; F. } \\
\text { Consorti, SIPeM (Società Italiana di Pedagogia Medica); L. } \\
\text { Coppola, DG Welfare Regione Lombardia; R. D'Elia, } \\
\text { Ministero della Salute, Direzione Generale della } \\
\text { Prevenzione; D. D'Ugo, SICO (Società Italiana Chirurgia } \\
\text { Oncologica), Università Cattolica del Sacro Cuore, Roma; F } \\
\text { De Lorenzo, European Cancer Patients Coalition, FAVO } \\
\text { (Federazione Italiana Associazioni di Volontariato in } \\
\text { Oncologia); F. Donatelli, Università degli Studi di Milano, } \\
\text { Istituto Clinico Sant'Ambrogio Gruppo San Donato; A. Fauci, } \\
\text { Istituto Superiore di Sanità; F. Giardina, CNOP (Consiglio } \\
\text { Nazionale Ordine degli Psicologi); P. lannone, Istituto } \\
\text { Superiore di Sanità; D. Mannino, AMD (Associazione Medic }\end{array}$ \\
\hline
\end{tabular}




\begin{tabular}{|c|c|c|}
\hline & & $\begin{array}{l}\text { Diabetologi); D. Mari, Fondazione IRCSS Ca'Grande - } \\
\text { Ospedale Maggiore Policlinico, Università degli Studi di } \\
\text { Milano; V. Mastrilli, Ministero della Salute, Direzione } \\
\text { Generale della Prevenzione; P. Mocarelli, IRCCS } \\
\text { Fondazione Don Gnocchi; E. Molinari, Università Cattolica } \\
\text { del Sacro Cuore, Milano, Istituto Auxologico Italiano; F. } \\
\text { Molteni, Villa Beretta - Presidio di Riabilitazione } \\
\text { dell'Ospedale Valduce; A. Muratore, SICO (Società Italiana } \\
\text { Chirurgia Oncologica); G. Muttillo, IPASVI (Infermieri } \\
\text { Professionali, Assistenti Sanitari e Vigilatrici di Infanzia); G. } \\
\text { Perseghin, SID (Società Italiana Diabetologia); G. Pintori, } \\
\text { Inversa Onlus (associazione italiana per i pazienti affetti da } \\
\text { idrosadenite suppurativa-acne inversa-); E. Previtali, AMICI } \\
\text { Onlus (Associazione Nazionale per le Malattie Infiammatorie } \\
\text { Croniche dell'Intestino); W. Ricciardi, Istituto Superiore di } \\
\text { Sanità; E. Rizzato, Fondazione SPP (Scuola di Sanità } \\
\text { Pubblica); E. Santoro, IRCCS - Istituto di Ricerche } \\
\text { Farmacologiche "Mario Negri"; G. Spata, FNMCeO } \\
\text { (Federazione Italiana Ordine dei Medici); M. Tessarollo, } \\
\text { Residenze Anni Azzurri (Gruppo KOS); R. Valdagni, IRCCS } \\
\text { Istituto Nazionale dei Tumori. }\end{array}$ \\
\hline Panel Jury & $\begin{array}{l}\text { Had the authority to: } \\
\text { - } \quad \text { write a regulation of discussion in which the methods } \\
\text { and procedures that the Jury will apply internally are } \\
\text { defined a priori, including the composition of the } \\
\text { Writing Committee; } \\
\text { read and evaluate the documents produced from the } \\
\text { work groups; } \\
\text { assist to the presentation and discussion of the } \\
\text { reports during the meetings of the Consensus } \\
\text { Conference; } \\
\text { discuss, review and approve the preliminary } \\
\text { consensus document to present at during closing } \\
\text { time of the conference; } \\
\text { review and approve the final consensus document } \\
\text { according to the modalities and times provided by } \\
\text { the regulation. }\end{array}$ & $\begin{array}{l}\text { A. Aglione, FAVO (Federazione Italiana Associazioni di } \\
\text { Volontariato in Oncologia); G. Artioli, Arcispedale Santa } \\
\text { Maria Nuova - IRCCS di Reggio Emilia; F. Avolio, Agenzia } \\
\text { Regionale Sanitaria della Puglia; European Innovative } \\
\text { Partnership for Active Healthy Ageing; C. Colombo, IRCSS } \\
\text { Istituto di Ricerche Farmacologiche Mario Negri, Milano; S. } \\
\text { Leone, A.M.I.C.I. Italia Onlus (Associazione Nazionale per le } \\
\text { Malattie Infiammatorie Croniche dell'Intestino); M.C. } \\
\text { Ghiotto, Regione del Veneto; B. Mazzoleni, Commissione } \\
\text { Nazionale Ipasvi (Infermieri professionali, assistenti sanitari } \\
\text { e vigilatrici di infanzia); R. Mete, Istituto Superiore di Studi } \\
\text { Sanitari, Giuseppe Cannarella; P. Mosconi, IRCSS Istituto di } \\
\text { Ricerche Farmacologiche Mario Negri, Milano; S. Nardi, } \\
\text { Coordinamento nazionale delle Associazioni di Malati } \\
\text { Cronici (CnAMC); C. Pinto, AIOM (Associazione Italiana } \\
\text { Oncologia Medica); P. Quintaliani, SIN (Società Italiana } \\
\text { Nefrologia), FIR (Fondazione Italiana Rene); G. Sanna, } \\
\text { METIS FIMMG (Federazione italiana medici di medicina } \\
\text { generale); S. Tonolo, ANMAR (Associazione Nazionale } \\
\text { Malati Reumatici); A. Virzì, Società di Medicina Narrativa }\end{array}$ \\
\hline $\begin{array}{l}\text { President of the } \\
\text { Jury }\end{array}$ & $\begin{array}{l}\text { Had the authority to: } \\
\text { - } \quad \text { write the work regulation and get the Jury's } \\
\text { members to approve it; } \\
\text { - } \\
\text { verify that all the members of the Jury promptly } \\
\text { receive the materials produced by the experts and } \\
\text { work groups; } \\
\text { - } \\
\text { coordinate the Jury and the Writing Committee until } \\
\text { the writing of the final consensus document; } \\
\text { - } \quad \text { regulate the unfolding of the Jury's discussions, } \\
\text { ascertain the poll results and countersign the } \\
\text { meeting's reports; } \\
\text { maintain the relationships with the Organization } \\
\text { Committee and act as a conduit for communications } \\
\text { directed to the Jury; } \\
\text { take part in the celebration of the Consensus } \\
\text { Conference; } \\
\text { publicly communicate, at the end of the Jury's } \\
\text { discussion, the conclusions reported in the } \\
\text { approved preliminary consensus document. }\end{array}$ & $\begin{array}{l}\text { G. Damiani, Policlinico Universitario Agostino Gemelli, } \\
\text { Università Cattolica del Sacro Cuore, Roma }\end{array}$ \\
\hline $\begin{array}{l}\text { Writing } \\
\text { Committee }\end{array}$ & $\begin{array}{l}\text { Formed by members selected from the Jury, this } \\
\text { Commitee reflects the competences and characteristics } \\
\text { of the Panel's multidisciplinarity, provided the newsroom } \\
\text { with the final consensus document, following the } \\
\text { modalities established and described in the Jury }\end{array}$ & $\begin{array}{l}\text { F. Avolio, Agenzia Regionale Sanitaria della Puglia; } \\
\text { European Innovative Partnership for Active Healthy Ageing; } \\
\text { G. Artioli , IPASVI Emilia Romagna (Infermieri professionali, } \\
\text { assistenti sanitari e vigilatrici di infanzia), Università degli } \\
\text { studi di Parma; S. Leone, A.M.I.C.I. Italia Onlus }\end{array}$ \\
\hline
\end{tabular}




\begin{tabular}{|c|c|c|}
\hline & $\begin{array}{l}\text { regulation. This document is an integration of the } \\
\text { preliminary document that the Jury will produce in the } \\
\text { hours following the Consensus Conference with a } \\
\text { synthesis of the tasks that the Panel based itself on to } \\
\text { formulate the recommendations. Moreover, the Writing } \\
\text { Committee verified the coherence between the } \\
\text { conclusions and the accompanying texts. }\end{array}$ & $\begin{array}{l}\text { (Associazione Nazionale per le Malattie Infiammatorie } \\
\text { Croniche dell'Intestino); P. Mosconi, IRCSS Istituto di } \\
\text { Ricerche Farmacologiche Mario Negri, Milano }\end{array}$ \\
\hline $\begin{array}{l}\text { Scientific } \\
\text { Secretariat }\end{array}$ & $\begin{array}{l}\text { coordinated the collected and exchanged material and } \\
\text { information between the different participants involved }\end{array}$ & $\begin{array}{l}\text { G. Graffigna, Università Cattolica del Sacro Cuore, Milano; } \\
\text { S. Barello, Università Cattolica del Sacro Cuore, Milano }\end{array}$ \\
\hline $\begin{array}{l}\text { Organizational } \\
\text { Secretariat }\end{array}$ & coordinated the operative organization of the conference & $\begin{array}{l}\text { J. Menichetti, Università Cattolica del Sacro Cuore, Milano; } \\
\text { M. Savarese, Università Cattolica del Sacro Cuore, Milano }\end{array}$ \\
\hline $\begin{array}{l}\text { Members of the } \\
\text { Expert Meetings }\end{array}$ & $\begin{array}{l}\text { Held the role of assessing and synthesizing the evidence } \\
\text { present in literature that were pertinent to the queries of } \\
\text { the Consensus Conference. Particularly, they had the } \\
\text { following jobs: } \\
\text { - } \quad \text { preparing a synthesis of the scientific evidence } \\
\text { available on the subject; } \\
\text { - preparing a synthesis of the information available to } \\
\text { the public that comes from different sources, } \\
\text { regarding the subjects of interest in the conference; } \\
\text { - } \quad \text { handing the reports made to the Jury, within the } \\
\text { stipulated times; } \\
\text { presenting the data collected during the celebration } \\
\text { of the conference and participate in the discussion. }\end{array}$ & 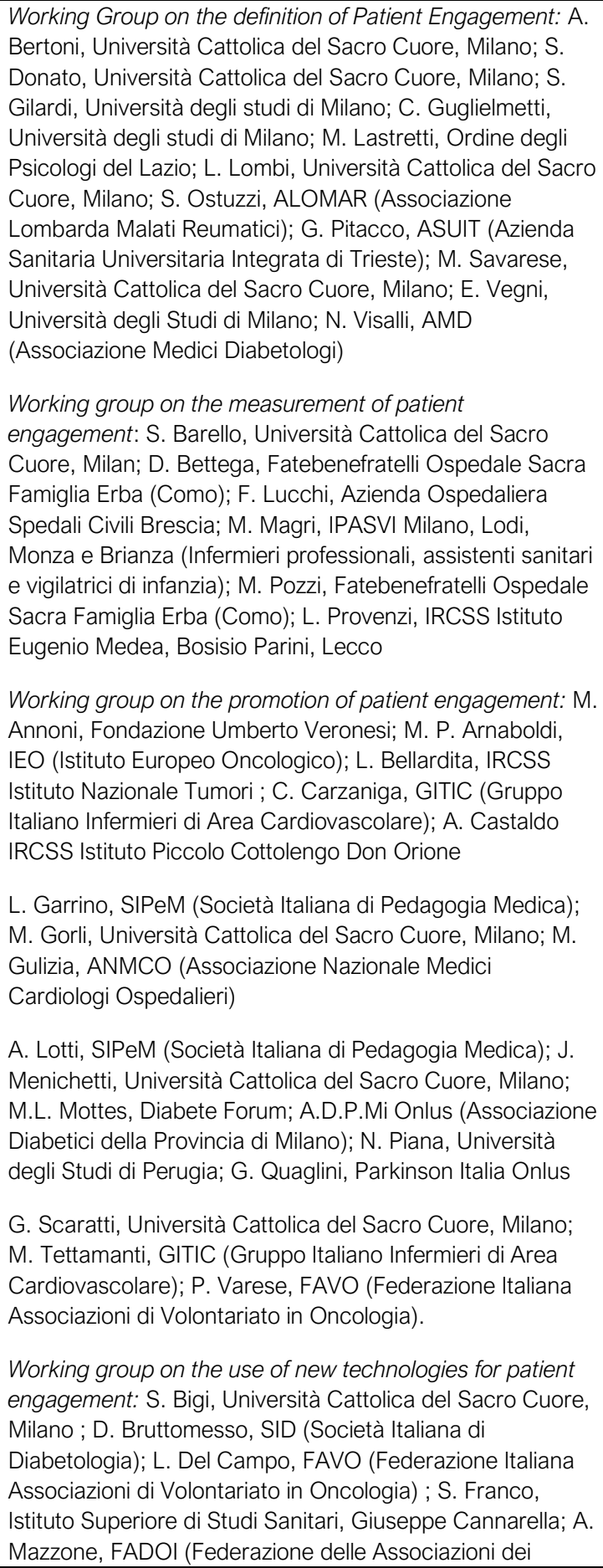 \\
\hline
\end{tabular}




\begin{tabular}{|l|l|l|}
\hline & $\begin{array}{l}\text { Medici Internisti Ospedalieri) ; G. Palumbo Villa Beretta - } \\
\text { Presidio di Riabilitazione dell'Ospedale Valduce; D. Pero } \\
\text { AIMAC (Associazione Italiana Malati di Cancro); G. Pintori, } \\
\text { Inversa Onlus; G. Polvani, Università degli Studi di Milano, } \\
\text { IRCSS Centro Cardiologico Monzino }\end{array}$ \\
& $\begin{array}{l}\text { E. Santoro, IRCCS - Istituto di Ricerche Farmacologiche } \\
\text { "Mario Negri" ; S. Triberti, Università Cattolica del Sacro } \\
\text { Cuore, Milano; A. Tzannis, Università Cattolica del Sacro } \\
\text { Cuore, Milano }\end{array}$ \\
\hline
\end{tabular}

An Organizational Committee together with the Technical-Scientific Committee supervised the whole process to guarantee its methodological standard. Further experts were involved in four thematic working group which had to synthetize, discuss and report on the scientific evidences in response to the four questions of the project. Experts meetings were held to assess, discuss and synthesize the evidences produced in the previous literature analysis and ad hoc survey. Four Working Groups were organized: one to respond to each of the Consensus Conference questions, as described below:

(1) Working Group on the definition of Patient Engagement, to evaluate, select and synthesize all the available evidence regarding the main definitions of Patient Engagement available and the conceptual boundaries between Patient Engagement and other related concepts (e.g. Patient empowerment, Patient Activation, Health literacy, Patient Adherence). Finally they had to discuss and define the main obstacles and the main enablers of Patient Engagement.

(2) Working Group on the measurement of Patient Engagement to evaluate, select and synthesize all the available evidence regarding the main instruments used for the measurement of Patient Engagement, of Caregiver/Family Engagement and of the healthcare professionals attitudes to promote Patient Engagement.

(3) Expert Meetings on the promotion of Patient Engagement to evaluate, select and synthesized the available evidence regarding the main methods and instruments for the promotion of Patient Engagement.

(4) Expert Meetings on the role of new technologies for Patient Engagement to evaluate, select and synthesize the available evidence regarding the types of technologies more effective in the promotion of Patient Engagement and the main barriers or facilitators to the adoption of new technologies for the promotion of Patient Engagement.

Finally a Panel of Jury had to revise and rate the evidences produced by the experts to finalize the final consensus document with shared recommendations. The Panel of Jury was composed of members selected from the Organizing Committee on the base of intellectual autonomy criteria, representativeness, authority in the scientific field and moral and cultural intellect, in order to guarantee multi-disciplinarily and multi-professionality. It met at the end of the consensus process to read and evaluate the documents produced from the experts meeting. The Panel of Jury also discussed, drafted and approved the consensus document. 


\section{Results}

The final Consensus report (extensively reported elsewhere (46)) was prepared by the Panel of Jury on the basis of the deep consideration, evaluation and rating of all the evidences reported by experts in the documentation provided. The main recommendations reported in the final Consensus Statement are summarized in the following paragraphs.

\subsection{Query 1 - What is the definition of Patient Engagement?}

It was decided to avoid the term "patient" because conceptually too passivizing and not coherent with the goal of encouraging the individual's active role. The word patient comes from the Latin word patiens, the present participle of the deponent verb, patior, meaning 'I am suffering' and akin to the Greek verb

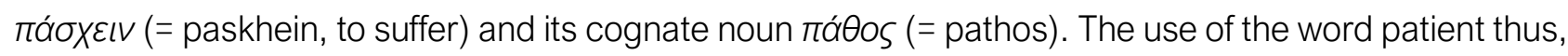
implicitly evokes a negative an asymmetric relationship between an "expert" (i.e. the healthcare professionals) and a "lay" person who have to be changed in some extent. Thus, rather than of "patients" it appears preferable to refer to "persons" with a demand of health or care. Furthermore, the Consensus Conference recommends adopting the term "Engagement" without pinning it to a specific actor (i.e. the patient) to underline the relational nature of this concept. "Engagement", indeed, is a concept which identifies and qualifies the possible relationships that a person may entertain with the healthcare system in its whole: namely with its health and/or care condition (i.e. individual's level of psychological adjustment to the disease); with his/her informal caregiver (the family in particular); with his/her healthcare professionals; with society and so on. Thus, "Engagement" has to be conceived as a systemic and organizational phenomenon since it results from a combination of multilevel factors of individual, relational, organizational, social and political nature. On these basis, "Engagement" needs to be considered as an umbrella concept that articulates, systemizes and includes other such as adherence, compliance, empowerment, activation, health literacy, shared decision making, and activation as described in Supplementary file 1.

\subsection{Query 2 - How measuring Patient Engagement?}

Individual differences of how people react and respond to their own health's management needs are important to consider for a better personalization of social and healthcare services. Furthermore, the assumption that people of the same clinical or socio-cultural characteristics necessarily respond in the same manner to the proposal of taking a proactive role in their health managements is misleading and risky. Assessing the degree of emotional elaboration and adaptation to the illness and its management is key to support patients' motivation in the involvement in the clinical care journey. At the same time, the needs and aptitudes of the professionals and the team towards the development of Engagement are aspects that need just as much monitoring. According to the Consensus Conference, a cultural and 
organizational reconfiguration of the social/health and welfare services in favour of the inclusion of nonextemporary opportunities of assessment and monitoring of Engagement is very desirable. The integrated assessment, as an inspiring principle and value within the organizational and social healthcare system, is to be considered the primo movens of the promotion of Engagement. The assessment implies the monitoring across time, of different operational levels (micro-meso-macro) of the actors and the social and health care system and requires multiple scientifically validated methods and instruments. Furthermore the assessment of Engagement should not be addressed only to the "receivers of care", but also to their families and even to the healthcare professionals. Assessing the level of Engagement of individuals with chronic illness and their informal/family caregivers in the clinical care process should become a routine operation within clinic practice. It's necessary to adopt assessment measures that are validated and reliable in order to evaluate the efficacy/efficiency of the interventions done, and to orient and personalise them based on the characteristics of the recipients and the complexity of their clinical care case. Just as important is the evaluation of the aptitude (difficulty/resistance) and the behaviours of the professionals and team towards the active role of the individual with chronic illness and his formal/informal caregivers. Healthcare professionals skills/knowledge for the efficient promotion of Engagement need to be assessed and trained too. Furthermore, the adoption of Engagement assessment tools should be seen as a way to guarantee that the voices of all the key stakeholders of a healthcare system are listened in the goal of realising a really value base healthcare.

For a broader vision of the instruments available for the assessment of Engagement refer to Table 3. It appears necessary to adopt articulated devices to monitor the system of activities/practices that occur in the organization context such as, for example, the Change Laboratories or the instruments of organizational ethnography.

Table 3 Instruments for Engagement assessment

\begin{tabular}{|c|c|c|c|}
\hline Scale name & Characteristics & Pros & Cons \\
\hline \multicolumn{4}{|c|}{ Patient Engagement assessment scales } \\
\hline $\begin{array}{l}\text { Altarum Consumer } \\
\text { Engagement (ACE) } \\
(47)\end{array}$ & $\begin{array}{l}15 \text { item scale that assesses the individual's } \\
\text { behaviour in managing his health and his } \\
\text { decision-making regarding heath care. The } \\
\text { instrument is formed by four sub-scales } \\
\text { (commitment, informed choice, navigation, } \\
\text { ownership) each indicative of a specific aspect } \\
\text { of Engagement. }\end{array}$ & $\begin{array}{l}\text { The scale is very articulated } \\
\text { and detailed and allows for a } \\
\text { good assessment of the } \\
\text { individual's } \\
\text { management skill. }\end{array}$ & $\begin{array}{l}\text { The scale is quite long } \\
\text { and complicated in its } \\
\text { clinical application. The } \\
\text { scale does not measure } \\
\text { the emotional- } \\
\text { motivational component } \\
\text { of Engagement. }\end{array}$ \\
\hline $\begin{array}{l}\text { Patient Activation } \\
\text { Measure (PAM) } \\
(48)\end{array}$ & $\begin{array}{l}\text { Scale formed by } 13 \text { items that assesses the } \\
\text { person's current behavioural abilities in } \\
\text { managing the illness and the treatment } \\
\text { prescriptions. }\end{array}$ & $\begin{array}{l}\text { The scale is broadly used } \\
\text { and has validation in several } \\
\text { languages }\end{array}$ & $\begin{array}{l}\text { It focuses on the } \\
\text { behavioral and cognitive } \\
\text { components of } \\
\text { Engagement, and does } \\
\text { not analyze the emotional- } \\
\text { motivational component } \\
\text { of Engagement }\end{array}$ \\
\hline $\begin{array}{l}\text { Patient Health } \\
\text { Engagement Scale } \\
\text { (PHE-S) } \\
(49)\end{array}$ & $\begin{array}{l}5 \text { item scale developed based on a solid } \\
\text { conceptual evidence-based model of the } \\
\text { individual with chronic illness' experience of } \\
\text { Engagement (PHE-model). } \\
\text { The scale assesses the ability to reconfigure } \\
\text { ones' identity from passive receiver to co- } \\
\text { author of the heath service. }\end{array}$ & $\begin{array}{l}\text { The scale is easy and fast to } \\
\text { use in the clinical context. } \\
\text { The scale is well reliable in } \\
\text { measuring the } \\
\text { psychological attitude of } \\
\text { patients towards } \\
\text { Engagement }\end{array}$ & $\begin{array}{l}\text { The scale does not } \\
\text { measure behavioural } \\
\text { components of the } \\
\text { individual's self- } \\
\text { management. }\end{array}$ \\
\hline
\end{tabular}


Family and Caregiver Engagement assessment scales

\begin{tabular}{|c|c|c|c|}
\hline \multicolumn{4}{|c|}{ Family and Caregiver Engagement assessment scales } \\
\hline $\begin{array}{l}\text { Preparedness for } \\
\text { caregiving scale } \\
(50)\end{array}$ & $\begin{array}{l}\text { An } 8 \text { item questionnaire (validated on a } \\
\text { psychometric level) created to assess how } \\
\text { much the caregiver perceives himself as } \\
\text { prepared to deal with the assistive role on } \\
\text { various levels (physical care, emotional } \\
\text { support, stress management). }\end{array}$ & $\begin{array}{l}\text { The scale is articulated and } \\
\text { complete and offers an } \\
\text { adequate measurement of } \\
\text { the caregiver's } \\
\text { competences in care-taking } \\
\text { as well as his psychological } \\
\text { adjustment in having this } \\
\text { role. }\end{array}$ & $\begin{array}{l}\text { The scale was developed } \\
\text { and validated for the } \\
\text { neurological and } \\
\text { oncological field and was } \\
\text { never used in other } \\
\text { therapeutic areas. }\end{array}$ \\
\hline $\begin{array}{l}\text { Parent-Patient } \\
\text { activation measure } \\
\text { (51) }\end{array}$ & $\begin{array}{l}\text { It's the caregiver version of the } 13 \text { item scale } \\
\text { that measures the individual's activation in self- } \\
\text { managing his healthcare. Particularly, this } \\
\text { scale assesses the level of the caregiver's } \\
\text { activation, evaluating his knowledge, his } \\
\text { perceived self-efficacy and his desire to take an } \\
\text { active role in managing the healthcare of his } \\
\text { loved one. }\end{array}$ & $\begin{array}{l}\text { The scale allows to assess } \\
\text { the caregiver's activation in } \\
\text { a way specular to the one } \\
\text { of the person with chronic } \\
\text { illness. }\end{array}$ & $\begin{array}{l}\text { The scale is specific for } \\
\text { the paediatric area. }\end{array}$ \\
\hline \multicolumn{4}{|c|}{ Scales for the assessment of the healthcare professional's aptitudes for Patient \& Caregiver Engagement } \\
\hline $\begin{array}{l}\text { Clinician Support for } \\
\text { Patient Activation } \\
\text { Measure - CS-PAM } \\
\text { (52) }\end{array}$ & $\begin{array}{l}\text { Instrument that allows assessing the attitudes } \\
\text { and value orientation of the clinicians towards } \\
\text { the activation of the person with chronic illness. }\end{array}$ & $\begin{array}{l}\text { It is proposed as a measure } \\
\text { of activation specular to the } \\
\text { measurements of the } \\
\text { person and caregiver's } \\
\text { activation and allows for a } \\
\text { triangulation of this data. }\end{array}$ & $\begin{array}{l}\text { It's an aptitude } \\
\text { assessment scale that } \\
\text { does not evaluate the } \\
\text { actual clinician's } \\
\text { Engagement abilities. }\end{array}$ \\
\hline $\begin{array}{l}\text { Self-Management } \\
\text { Support (SMS) Scale } \\
\text { (53) }\end{array}$ & $\begin{array}{l}\text { Behavioural scale that seeks to measure how } \\
\text { much clinicians use strategies to improve the } \\
\text { individual's self-management competences. }\end{array}$ & $\begin{array}{l}\text { Offers a list of prototypical } \\
\text { behaviours that } \\
\text { characterize the clinician's } \\
\text { abilities to motivate and } \\
\text { educate the person in self- } \\
\text { management. }\end{array}$ & $\begin{array}{l}\text { It doesn't assess the } \\
\text { clinician's attitudes and } \\
\text { his value orientation for } \\
\text { Engagement. }\end{array}$ \\
\hline $\begin{array}{l}\text { Clinicians } \\
\text { Competence in } \\
\text { Patient Engagement } \\
\text { Strategies (CC-PES) } \\
\text { (54) }\end{array}$ & $\begin{array}{l}\text { The scale is articulated in } 9 \text { items and assesses } \\
\text { the clinician's self-efficacy perceptions } \\
\text { concerning the different fundamental strategies } \\
\text { for the promotion of the person's Engagement. }\end{array}$ & $\begin{array}{l}\text { The scale was created and } \\
\text { validated specifically to } \\
\text { measure the clinician's } \\
\text { Engagement competences } \\
\text { and perceived Engagement } \\
\text { efficacy }\end{array}$ & $\begin{array}{l}\text { It's based on the } \\
\text { clinician's self-evaluation. }\end{array}$ \\
\hline
\end{tabular}

\subsection{Query 3 - What are the most recommended methodologies and the tools to promote Patient Engagement?}

It's necessary to avoid a simplistic approach to the promotion of Engagement, by limiting it to matters concerning just the individual patient. Therefore the Consensus Conference recommends to develop an "eco-system" of actions of Engagement promotion on different levels: individual, interpersonal, organizational, social-community, and political/institutional, as detailed described in Supplementary file 2. 
1) At the level of individuals, it is necessary to support their engagement skills and their sense of ownership over the healthcare course. Interventions designed and structured on the basis of a scientific framework of Engagement and personalized based on the assessment of individuals' needs and availability to take ownership over their health management. To achieve this goal, the following are recommended: 1) Therapeutic education and peer education; 2) Motivational strategies and counselling; 3) Implementing psychology counselling interventions to increase motivation and self-awareness. In this direction the following strategies should be considered: Health Coaching(55-57), Motivational Interviews(58), Goal Setting(59,60), Medical Humanities(61-64), and Mindfulness(65,66).

2) The healthcare professional's participation within this cultural shift and the support to their knowledge and skill acquisition for Engagement promotion is crucial in order to avoid psychological resistances and to have them "on board". To sensitise, train and involve healthcare professionals and the healthcare unit team, it's necessary to promote an "Engagement culture" through concrete actions such as: 1) Providing, starting from the university health professionals' educational curricula as well as in continuous training, knowledge and specific skills for the promotion of Engagement in the daily clinical practice; 2) Promote the health professional's well-being and Engagement and motivate him towards initiatives of Engagement promotion; 3) Promote healthcare unit teams that are multi-professional and multidisciplinary is a prerequisite. To achieve these goals recommended strategies are: Inter-professional Education(67-69), Problem Based Learning(70,71), appeal to Expert Patient(21,22,72) such as sensitizers and educators; multidisciplinary and inter-professional consulting for a better care of the individual(73,74); technologies as facilitators for the communication and sharing of clinical data between among health practitioners $(75,76)$.

3) Promoting Engagement of family members and informal caregivers, through specific intervention of education and sensitization, is an important resource to strengthen the efficacy of the preventive or therapeutic intervention. Focusing only on the people with illness is reductive and imprecise, as more often than not the person with chronic illness is not alone in his encounter with the healthcare professionals, nor in taking charge of the management of his health. When the caregiver becomes an active part of the healthcare team and gains knowledge regarding the value of his role, he contributes to the increase of the potential of therapeutic success of the interventions both in short and long term. The malaise or hyper-protective ways he uses with the assisted person, moreover, could jeopardize the person with chronic illness' abilities to actively participate in the healthcare journey. In relation to the informal/family caregivers, there is a need for: 1) resources that guarantee efficacy, sustainability and continuity of the interventions in the long run; 2) emotional support and counselling; 3) caregiver education and improvement of health literacy. To achieve these goals recommended strategies are: Therapeutic Education(34) and Peer Education(79,80) and Psychology Counselling(81) to increase motivation and self-awareness of the informal caregivers. 
4) Models, processes, and practices of the social and healthcare organization should be reconfigured in order to truly achieve the goal of Engagement. To opt for a personalized care intervention and a better continuity of social welfare services are conceived as fundamental precursor of patient engagement. In this direction the following priorities are recommended: 1) Integration of assistive, social and care services; 2) the establishments of Case Managers(82), the continuity and personalization of social welfare and care interventions; 3) systematic stakeholders' involvement in the co-design and coproduction of care services(83,84);

5) Association formed by people with chronic illness, caregivers and volunteers can act as glue of the different functions and organizations that are responsible for the management of the person with chronic illness. They are a priceless source of education, information, practical and especially emotional support for the assisted and their families $(85,86)$. The valorisation and support of the role of Associations of people with chronic illnesses or citizen's organisations within the "eco-system" for the promotion of Engagement benefits the assisted, his informal/family caregiver and the social and healthcare system itself, both in terms of protection of their rights and of promotion of the knowledge and exercise of the duties of the people thanks to their irreplaceable contribution in the realization of their health plan.

6) Finally, the promotion of initiatives of social and public opinion information and sensitisation on the value of Engagement is to be considered. Society, in particular peer networks, can have a crucial role in the promotion of Engagement for the individual and his informal caregiver. Social sensitisation and informative initiatives on the value of engagement as well as a transparent analysis of the challenges encountered by individuals in the Engagement process are desirable. Sensitisation and informative campaigns, even with a social marketing approach, can be useful in the achievement of this goal $(87,88)$.

\subsection{Query 4 - What is the role of the new technologies in the promotion of Patient Engagement?}

Technology can be considered as a facilitator of Engagement and could be integration to other types intervention strategies. Technological intervention supports Engagement, and it is not substitutive of the relationship between the individual and his assisting team. Technologies should be considered as one of the possible means of intervention to promote Engagement, and not an end in itself. Technological interventions for the promotion of Engagement should be perceived as integrative and complementary and not substitutive to the traditional strategies and interventions for the education and support of the individual. The efficacy of technological intervention is in function of the assistive and cure relationship. Moreover, it's necessary to avoid the risk that these are developed and used exclusively as something "imposed from above" (i.e. the welfare system) for the person with chronic illness. Technologies should be designed as customizable based on the specific level of Engagement previously measured with adequate and scientific instruments, derived from an analysis of the Engagement needs of the different actors, to improve the personalization of the technological intervention(89). It's important to involve the 
final users (people with chronic illness and their caregivers) in the design and implementation of the technology to allow it to be able to respond to the specific needs of the different phases of Engagement. It's also crucial to develop technologies that act in a systemic way on the diverse drivers of Engagement (to allow for the integration and connection of the different actors of the welfare ecosystem) and acculturate and sensitize the health facilities and professionals in the adoption of new technologies for the promotion of Engagement (training initiatives...)(90). Furthermore, the project and implementation of technological initiatives for the promotion of Engagement should be perceived/created in collaboration with the healthcare structure and the professionals in order to guarantee the best possible alignment of healthcare models and practices, with the information systems and with the routines/procedures currently in use. The health facility, in turn has to promote the definition of policies, principles and criteria aimed at regulating the design and implementation of initiatives for the promotion of Engagement, that are able to guarantee and safeguard people's health. However, efficacy assessment, feasibility as well as regulatory mechanisms and certification criteria must be provided for an appropriate use of these instruments.

\section{Discussion}

Engagement promoting strategies can vary depending on clinical conditions and the seriousness of symptoms: it's important to adopt a systemic approach that takes into account the potential obstacles that may be present at different levels. A systematic view of interventions can counter more efficiently to the complexity of Engagement, avoiding a reductive view with subsequent supply of interventions that are fragmented and badly coordinated. Engagement should become an integrating part of organizational models that call for the realization of care continuity in the treatment of chronic illnesses with the empowerment of "out of office" actions, meaning in alternative contexts, linked to the person's life circumstances and situations, to his/her sensibility and his/her interests which appear to be functional when integrated with Engagement promoting strategies. Furthermore, the adoption of instruments for the assessment of the level of engagement of a person with chronic illness and/or his informal caregiver, represents a crucial strategy to overcome the "one size fits all" logic, and instead move in the direction of modular actions, that can be tuned in progress throughout the person's clinical care journey. Finally, the "patient" is not the unique actor that needs to be considered and support to achieve the Engagement goal; on the contrary an eco-system of actions should be enacted at the different levels (i.e. micro-mesomacro) and addressed to the different stakeholders (i.e. patients, family caregivers, healthcare professionals, society, organizations and peer networks) (Figure 2). 


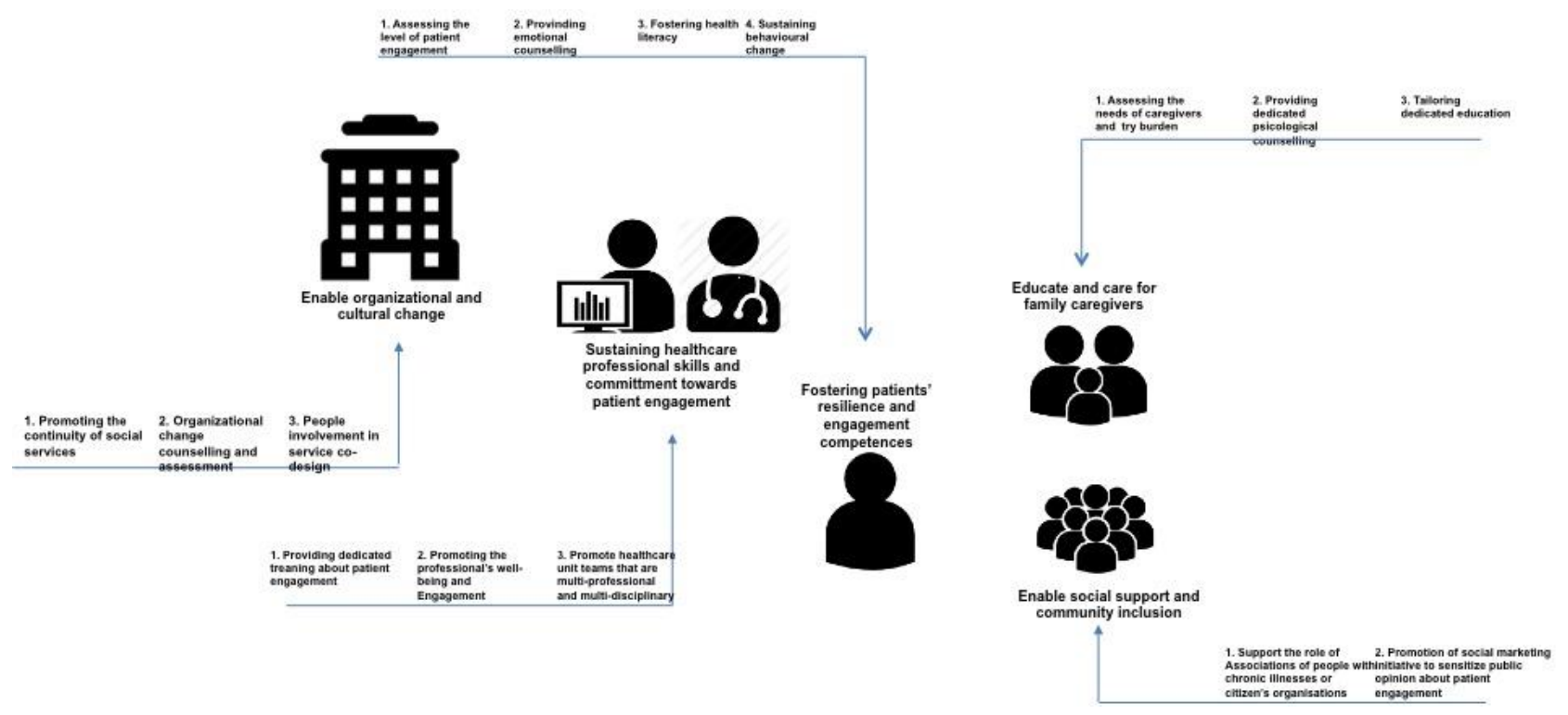

\section{Conclusions}

This consensus conference was established in response to concerns about the rapid increase in the number of patient engagement initiatives that were being developed around the world. The Consensus Conference prioritised the need for a set of criteria to guide the quality appraisal of patient engagement interventions. The purpose of this work is to enhance the quality and effectiveness of patient engagement strategies by establishing a shared evidence framework for the content, development, implementation and evaluation of them.

The recommendations drafted from the Consensus Conference should not be conceived as strict guidelines to practice, rather a scientific systematization of best practices often fragmented and jeopardized in the medical sector. These recommendations should be envisaged as inspirational principles to promote a real eco-system of engagement, against a reductive and unrealistic approach to this issue. Finally, although the Consensus Meeting took place in Italy, the expert involved have a renowned international scientific and clinical expertise on the topic of the conference and they based their recommendation on international scientific evidences. However, a further cross-national validation of the recommendation provided by this consensus conference statement is advisable and is currently planned by the Authors.

Competing interests: none declared 


\section{References}

1. Geneau R, Stuckler D, Stachenko S, McKee M, Ebrahim S, Basu S, et al. Raising the priority of preventing chronic diseases: A political process. Vol. 376, The Lancet. 2010. p. 1689-98.

2. Suhrcke M, Nugent R a., Stuckler D, Rocco L. Chronic disease: an economic perspective. Health (San Francisco). 2006. 59 p.

3. Yach D, Hawkes C, Gould CL, Hofman KJ. The global burden of chronic diseases: overcoming impediments to prevention and control. JAMA [Internet]. 2004;291(21):2616-22. Available from: http://jama.jamanetwork.com/article.aspx?articleid=198852

4. Valentijn PP, Schepman SM, Opheij W, Bruijnzeels MA. Understanding integrated care: a comprehensive conceptual framework based on the integrative functions of primary care. Int $J$ Integr Care. 2013;13(1).

5. Couto JE, Comer DM. Patient engagement: the critical catalyst to health reform in the USA. J Comp Eff Res [Internet]. 2012 May [cited 2016 Jan 3];1(3):209-11. Available from: http://www.scopus.com/inward/record.url?eid=2-s2.0-84886945088\&partnerlD=tZOtx3y1

6. Clancy CM. Patient engagement in health care. Health Serv Res [Internet]. 2011 Apr [cited 2016 Jan 3];46(2):389-93. Available from: http://www.scopus.com/inward/record.url?eid=2s2.0-79952431179\&partnerlD=tZOtx3y1

7. Hochhalter AK, Song J, Rush J, Sklar L, Stevens A. Making the Most of Your Healthcare intervention for older adults with multiple chronic illnesses. Patient Educ Couns [Internet]. 2010 Nov [cited 2015 Nov 25];81(2):207-13. Available from: http://www.scopus.com/inward/record.url?eid=2-s2.0-77957284212\&partnerlD=tZOtx3y1

8. Greene J, Hibbard JH, Sacks R, Overton V, Parrotta CD. When patient activation levels change, health outcomes and costs change, too. Health Aff (Millwood) [Internet]. 2015 Mar 1 [cited 2015 Nov 16];34(3):431-7. Available from: http://www.scopus.com/inward/record.url?eid=2-s2.0-84924629092\&partnerlD=tZOtx3y1

9. Wagner PJ, Dias J, Howard S, Kintziger KW, Hudson MF, Seol Y-H, et al. Personal health records and hypertension control: a randomized trial. J Am Med Inform Assoc [Internet]. 2012 Jan [cited 2016 Jan 3];19(4):626-34. Available from: http://www.scopus.com/inward/record.url?eid=2-s2.0-84865095930\&partnerlD=tZOtx3y1

10. Ocloo J, Matthews R. From tokenism to empowerment: Progressing patient and public involvement in healthcare improvement. Vol. 25, BMJ Quality and Safety. 2016. p. 626-32.

11. Graffigna G. Promoting Patient Engagement and Participation for Effective Healthcare Reform. 2016.

12. Castro EM, Van Regenmortel T, Vanhaecht K, Sermeus W, Van Hecke A. Patient empowerment, patient participation and patient-centeredness in hospital care: A concept analysis based on a literature review. Vol. 99, Patient Education and Counseling. 2016. p. 
1923-39.

13. Elwyn G, Mb BA, Frcgp B, Crowe S, Dip PG, Ma MF, et al. Identifying and prioritizing uncertainties : patient and clinician engagement in the identification of research questions. 2010;16:627-31.

14. Barello S, Graffigna G, Vegni E, Savarese M, Lombardi F, Bosio AC. "Engage me in taking care of my heart": a grounded theory study on patient-cardiologist relationship in the hospital management of heart failure. BMJ Open [Internet]. 2015;5(3):e005582-e005582. Available from: http://bmjopen.bmj.com/cgi/doi/10.1136/bmjopen-2014-005582

15. Coulter A. Patient engagement—what works? J Ambul Care Manage. 2012;35:80-9.

16. Gruman J, Rovner MH, French ME, Jeffress D, Sofaer S, Shaller D, et al. From patient education to patient engagement: Implications for the field of patient education. Patient Educ Couns. 2010;78(3):350-6.

17. Barello S, Triberti S, Graffigna G, Libreri C, Serino S, Hibbard J, et al. eHealth for patient engagement: A Systematic Review. Front Psychol. 2016;6(JAN).

18. Hibbard JH, Greene J, Shi Y, Mittler J, Scanlon D. Taking the long view: how well do patient activation scores predict outcomes four years later? Med Care Res Rev [Internet]. 2015 Jun [cited 2016 Jan 3];72(3):324-37. Available from: http://www.scopus.com/inward/record.url?eid=2-s2.0-84930856664\&partnerlD=tZOtx3y1

19. Graffigna G, Barello S, Bonanomi A, Riva G. Factors affecting patients' online health information-seeking behaviours: The role of the Patient Health Engagement (PHE) Model. Patient Educ Couns. 2017;100(10).

20. Coulter A. Leadership for patient engagement. King's Fund [Internet]. 2012;20. Available from: http://www.kingsfund.org.uk/sites/files/kf/leadership-patient-engagement-angela-coulterleadership-review2012-paper.pdf

21. Greenhalgh T. Patient and public involvement in chronic illness: beyond the expert patient. BMJ. 2009;338.

22. Fox NJ, Ward KJ, O'Rourke AJ. The "expert patient": Empowerment or medical dominance? The case of weight loss, pharmaceutical drugs and the Internet. Soc Sci Med. 2005;60(6):1299-309.

23. Shaw J, Baker M. "Expert patient”—dream or nightmare? BMJ [Internet]. 2004;328(7442):723-4. Available from: http://www.bmj.com/content/328/7442/723.pdf+html\%5Cnhttp://www.bmj.com/content/328/74 42/723?tab=responses\%5Cnhttp://www.ncbi.nlm.nih.gov/pubmed/15044270

24. Parsons $S$, Winterbottom A, Cross $P$, Redding D. The quality of patient engagement and involvement in primary care. King's Fund. 2010;

25. Hardyman W, Daunt KL, Kitchener M. Value Co-Creation through Patient Engagement in Health 
Care: A micro-level approach and research agenda. Public Manag Rev [Internet]. 2015;17:90107. Available from: http://www.tandfonline.com/doi/abs/10.1080/14719037.2014.881539

26. Weil AR. The Patient Engagement Imperative. Health Aff (Millwood). 2016 Apr;35(4):563.

27. Carr AJ, Gibson B, Robinson PG. Is quality of life determined by expectations or experience ? 2001;322(May):1240-3.

28. Gibson A, Britten N, Lynch J. Theoretical directions for an emancipatory concept of patient and public involvement. Heal (United Kingdom). 2012;16(5):531-47.

29. Shoemaker SJ, Ramalho de Oliveira D, Alves M, Ekstrand M. The medication experience: preliminary evidence of its value for patient education and counseling on chronic medications. Patient Educ Couns [Internet]. 2011 Jun [cited 2016 Jan 5];83(3):443-50. Available from: http://www.scopus.com/inward/record.url?eid=2-s2.0-79958771044\&partnerID=tZOtx3y1

30. Fontaine P, Whitebird R, Solberg LI, Tillema J, Smithson A, Crabtree BF. Minnesota's Early Experience with Medical Home Implementation: Viewpoints from the Front Lines. J Gen Intern Med [Internet]. 2014 Dec 13 [cited 2015 Jan 30]; Available from: http://www.scopus.com/inward/record.url?eid=2-s2.0-84917690473\&partnerlD=tZOtx3y1

31. Rathert C, Brandt J, Williams ES. Putting the "patient" in patient safety: A qualitative study of consumer experiences. Heal Expect. 2012;15(3):327-36.

32. Hibbard JH, Greene J. What the evidence shows about patient activation: better health outcomes and care experiences; fewer data on costs. Health Aff (Millwood) [Internet]. 2013 Feb [cited 2014 Jul 9];32(2):207-14. Available from: http://www.scopus.com/inward/record.url?eid=2-s2.0-84874764000\&partnerlD=tZOtx3y1

33. Manary MP, Boulding W, Staelin R, Glickman SW. The Patient Experience and Health Outcomes. N Engl J Med [Internet]. 2013;368(3):201-3. Available from: http://www.nejm.org/doi/10.1056/NEJMp1211775

34. Barello S, Graffigna G. Engagement-sensitive decision making: Training doctors to sustain patient engagement in medical consultations. In: Patient Engagement: A Consumer-Centered Model to Innovate Healthcare. 2016. p. 78-93.

35. Williams N, Fleming C. Consumer and Provider Perspectives on Shared Decision Making : A Systematic Review of the Peer-Reviewed Literature. 2011;(September):1-4.

36. Légaré F. Shared decision making: moving from theorization to applied research and hopefully to clinical practice. Patient Educ Couns [Internet]. 2013 May [cited 2013 Oct 6];91(2):129-30. Available from: http://www.ncbi.nlm.nih.gov/pubmed/23561249

37. Makoul G, Clayman ML. An integrative model of shared decision making in medical encounters. In: Patient Education and Counseling. 2006. p. 301-12.

38. Elwyn G, Lloyd A, May C, van der Weijden T, Stiggelbout A, Edwards A, et al. Collaborative deliberation: A model for patient care. Patient Educ Couns [Internet]. 2014 Aug 13 [cited 2014 
Oct 24];97(2):158-64. Available from: http://www.ncbi.nlm.nih.gov/pubmed/25175366

39. Grande SW, Faber MJ, Durand MA, Thompson R, Elwyn G. A classification model of patient engagement methods and assessment of their feasibility in real-world settings. Patient Educ Couns. 2014;95:281-7.

40. Elwyn G, Frosch D, Thomson R, Joseph-Williams N, Lloyd A, Kinnersley P, et al. Shared decision making: A model for clinical practice. Vol. 27, Journal of General Internal Medicine. 2012. p. 1361-7.

41. Haase JE, Britt T, Coward DD, Leidy NK, Penn PE. Simultaneous Concept Analysis of Spiritual Perspective, Hope, Acceptance and Self-transcendence. Image J Nurs Scholarsh. 1992;24(2):141-7.

42. Walker LO, Avant KC. Strategies for theory construction in nursing 5th edition. Boston: Prentice Hall. 2011. 1-230 p.

43. Moher D, Liberati A, Tetzlaff J, Altman DG. Preferred reporting items for systematic reviews and meta-analyses: the PRISMA statement. BMJ. 2009;339(jul21 1):b2535-b2535.

44. Downs SH, Black N. The feasibility of creating a checklist for the assessment of inthe methodological quality both of randomised and \nnon-randomised studies of health care interventions. J Epidemiol Community Heal. 1998;52(6):377-84.

45. Aubut J-AL, Mehta S, Cullen N, Teasell RW, ERABI Group, Scire Research Team. A comparison of heterotopic ossification treatment within the traumatic brain and spinal cord injured population: An evidence based systematic review. NeuroRehabilitation. 2011;28(2):151-60.

46. Graffigna G, Barello S, Riva G, Castelnuovo G, Corbo M, Coppola L, et al. Promozione del patient engagement in ambito clinico-assistenziale per le malattie croniche : raccomandazioni dalla prima conferenza di consenso italiana. Recenti Prog Med. 2017;108:455-75.

47. Duke CC, Lynch WD, Smith B, Winstanley J. Validity of a New Patient Engagement Measure: The Altarum Consumer Engagement (ACE) Measure ${ }^{\mathrm{TM}}$. Patient [Internet]. 2015 Jun 23 [cited 2015 Nov 20];8(6):559-68. Available from: http://www.scopus.com/inward/record.url?eid=2s2.0-84948574520\&partnerlD=tZOtx3y1

48. Hibbard JH, Stockard J, Mahoney ER, Tusler M. Development of the patient activation measure (PAM): Conceptualizing and measuring activation in patients and consumers. Health Serv Res [Internet]. 2004;39(4 I):1005-26. Available from:

http://www.scopus.com/inward/record.url?eid=2-s2.0-3142668984\&partnerlD=tZOtx3y1

49. Graffigna G, Barello S, Bonanomi A, Lozza E. Measuring patient engagement: Development and psychometric properties of the patient health engagement (PHE) scale. Front Psychol. 2015;6(MAR).

50. Zwicker D. Preparedness for caregiving scale. Mov Disord. 2010;56(28):1-2. 
51. DeCamp LR, Leifheit K, Shah H, Valenzuela-Araujo D, Sloand E, Polk S, et al. Cross-cultural validation of the parent-patient activation measure in low income Spanish- and Englishspeaking parents. Patient Educ Couns. 2016;99:2055-62.

52. Hibbard JH, Collins PA, Mahoney E, Baker LH. The development and testing of a measure assessing clinician beliefs about patient self-management. Heal Expect. 2010;13(1):65-72.

53. Greene J, Sacks RM, Hibbard JH, Overton V. How much do clinicians support patient selfmanagement? The development of a measure to assess clinician self-management support. Healthcare. 2016;1-6.

54. Barello S, Guendalina G, Giuliana P, Maila M, Maurizio C, Livio P. An Educational Intervention to Train Professional Nurses in Promoting Patient Engagement: A Pilot Feasibility Study. Front Psychol. 2017;2020.

55. Palmer S, Tubbs I, Whybrow A. Health coaching to facilitate the promotion of healthy behaviour and achievement of health-related goals. Vol. 41, International Journal of Health Promotion and Education. 2003. p. 91-3.

56. Neuner-Jehle S, Schmid M, Grüninger U. The "Health Coaching" programme: a new patientcentred and visually supported approach for health behaviour change in primary care. BMC Fam Pract [Internet]. 2013;14:100. Available from:

http://www.pubmedcentral.nih.gov/articlerender.fcgi?artid=3750840\&tool=pmcentrez\&renderty pe=abstract

57. Caldwell KL, Gray J, Wolever RQ. The Process of Patient Empowerment in Integrative Health Coaching: How does it Happen? Glob Adv Heal Med [Internet]. 2013;2(3):48-57. Available from: http://journals.sagepub.com/doi/10.7453/gahmj.2013.026

58. Hettema J, Steele J, Miller WR. Motivational Interviewing. Annu Rev Clin Psychol. 2005;1(1):91-111.

59. Leach E, Cornwell P, Fleming J, Haines T. Patient centered goal-setting in a subacute rehabilitation setting. Disabil Rehabil. 2010;32(2):159-72.

60. Young D, Furler J, Vale M, Walker C, Segal L, Dunning P, et al. Patient Engagement and Coaching for Health: The PEACH study--a cluster randomised controlled trial using the telephone to coach people with type 2 diabetes to engage with their GPs to improve diabetes care: a study protocol. BMC Fam Pract [Internet]. 2007 Jan [cited 2015 Dec 18];8:20. Available from:

http://www.pubmedcentral.nih.gov/articlerender.fcgi?artid=1854904\&tool=pmcentrez\&renderty pe=abstract

61. Chiapperino L, Boniolo G. Rethinking Medical Humanities. J Med Humanit. 2014;35(4):377-87.

62. Jagsi R, Lehmann LS. The ethics of medical education. BMJ [Internet]. 2004 Aug 7;329(7461):332-4. Available from: 
http://www.pubmedcentral.nih.gov/articlerender.fcgi?artid=506856\&tool=pmcentrez\&rendertyp $\mathrm{e}=\mathrm{abstract}$

63. Doukas DJ, McCullough LB, Wear S. Perspective: Medical education in medical ethics and humanities as the foundation for developing medical professionalism. Acad Med [Internet]. 2012 Mar [cited 2013 Aug 25];87(3):334-41. Available from:

http://www.ncbi.nlm.nih.gov/pubmed/22373629

64. Bowman D. New perspectives in medical humanities. Medical Humanities. 2015;41(1):1.

65. Ludwig DS, Kabat-Zinn J. Mindfullness in Medicine. J Am Med Assoc. 2008;300(11):1350-2.

66. Hagan TL, Donovan HS. Ovarian cancer survivors' experiences of self-advocacy: a focus group study. Oncol Nurs Forum [Internet]. 2013 Mar [cited 2016 Jan 5];40(2):140-7. Available from: http://www.scopus.com/inward/record.url?eid=2-s2.0-84874591123\&partnerlD=tZOtx3y1

67. Swanwick T. Understanding Medical Education. In: Understanding Medical Education: Evidence, Theory and Practice: Second Edition. 2013. p. 1-6.

68. Collins LG, Arenson C, Antony R. Chronic illness care education: Longitudinal interprofessional mentor programme. Vol. 42, Medical Education. 2008. p. 1130-1.

69. Ross F, Harris R. Can interprofessional education make a difference in the care of people with chronic disease? Chronic IIIn. 2005;1(1):81-6.

70. Savery JR. Essential readings in problem-based learning: Exploring and extending the legacy of Howard S. Barrows. Essent Readings Probl Learn Explor Extending Leg Howard S Barrows. 2015;9(2):5-15.

71. Wood DF. ABC of learning and teaching in medicine: Problem based learning. BMJ [Internet]. 2003;326(7384):328-30. Available from:

http://www.bmj.com/cgi/doi/10.1136/bmj.326.7384.328

72. Wilson PM. A policy analysis of the Expert Patient in the United Kingdom: Self-care as an expression of pastoral power? Heal Soc Care Community. 2001;9(3):134-42.

73. Buljac-Samardzic M, Dekker-Van Doorn CM, Van Wijngaarden JDH, Van Wijk KP. Interventions to improve team effectiveness: A systematic review. Health Policy (New York). 2010;94:18395.

74. Epstein N. Multidisciplinary in-hospital teams improve patient outcomes: A review. Surg Neurol Int. 2014;5(8):295.

75. Gagnon M-P, Desmartis M, Labrecque M, Car J, Pagliari C, Pluye P, et al. Systematic review of factors influencing the adoption of information and communication technologies by healthcare professionals. J Med Syst. 2012;36(1):241-77.

76. Lluch M. Healthcare professionals' organisational barriers to health information technologies-A literature review. Int J Med Inform. 2011;80(12):849-62.

77. Guilbert JJ. Therapeutic patient education. Vol. 13, Education for Health. 2000. p. 419. 
78. Lagger G, Pataky Z, Golay A. Efficacy of therapeutic patient education in chronic diseases and obesity. Patient Educ Couns. 2010;79(3):283-6.

79. Sloane BC, Zimmer CG, Sloane BC. The power of peer health education. J Am Coll Health Assoc. 1993;41(6):241-5.

80. Turner G, Shepherd J. A method in search of a theory: peer education and health promotion. Heal Educ Res. 1999;14(2):235-47.

81. Counselling Psychology and Beyond. Counselling Psychology Quarterly. 1988;1(1):5-9.

82. Gary TL, Bone LR, Hill MN, Levine DM, McGuire M, Saudek C, et al. Randomized controlled trial of the effects of nurse case manager and community health worker interventions on risk factors for diabetes-related complications in urban African Americans. Prev Med (Baltim). 2003;37(1):23-32.

83. Freire K, Sangiorgi D. Service design \& healthcare innovation : from consumption to coproduction and co-creation. ServDes 2010 Second Nord Conf Serv Des Serv Innov. 2010;(1993):1-11.

84. Swan M. Health 2050: The Realization of Personalized Medicine through Crowdsourcing, the Quantified Self, and the Participatory Biocitizen. J Pers Med [Internet]. 2012;2(3):93-118. Available from: http://www.mdpi.com/2075-4426/2/3/93/htm

85. Baldwin M a. Patient advocacy: a concept analysis. Nurs Stand. 2003;17(21):33-9.

86. Negarandeh R, Oskouie F, Ahmadi F, Nikravesh M, Hallberg IR. Patient advocacy: Barriers and facilitators. BMC Nurs. 2006;5.

87. Lefebvre RC, Flora JA. Social Marketing and Public Health Intervention. Heal Educ Quaterly. 1988;15(3):299-315.

88. Gordon R, McDermott L, Stead M, Angus K. The effectiveness of social marketing interventions for health improvement: What's the evidence? Public Health. 2006;120(12):1133-9.

89. Graffigna G, Barello S, Triberti S, Wiederhold BK, Bosio AC, Riva G. Enabling ehealth as a pathway for patient engagement: A toolkit for medical practice. Annu Rev CyberTherapy Telemed. 2014;12:13-21.

90. James J. Health Policy Brief: Patient Engagement. Health Aff [Internet]. 2013;1-5. Available from: www.healthaffairs.org

\section{Figure legend}

Figure 1 The Consensus Conference phases

Figure 2 The patient engagement eco-system 